\title{
PENGARUH KEBIJAKAN DIVIDEN, KEPUTUSAN INVESTASI, UKURAN PERUSAHAAN DAN KEPEMILIKAN MANAJERIAL TERHADAP NILAI PERUSAHAAN
}

\author{
Mutmainnah $^{1}$, \\ Zarah Puspitaningtyas ${ }^{2}$, \\ Yeni Puspita ${ }^{3}$ \\ Universitas Jember \\ E-mail: zarah@unej.ac.id
}

\begin{abstract}
Effects of Dividend Policy, Investment Decisions, Firm Size and Managerial Ownership on Company Values. Firm value is investor's view on the company which is related with stock price that may foster a positive signal to open the investment opportunities. This research aims to determine the effect of dividend policy, investment decision, firm size and managerial ownership on firm value of consumer good industry sector at Indonesia Stock Exchange in 2013-2017. The sample is selected using purposive sampling method on 11 companies. Furthermore, the data is processed using multiple linear regression analysis. The Results of research showed that dividend policy and investment decision have significant positive effect on firm value. But firm size and managerial ownership have significant negative effect on firm value.
\end{abstract}

Keywords: Dividend policy, investment decision, firm size, managerial ownership, firm value

Abstrak: Pengaruh Kebijakan Dividen, Keputusan Investasi, Ukuran Perusahaan dan Kepemilikan Manajerial Terhadap Nilai Perusahaan. Nilai perusahaan adalah pandangan investor terhadap perusahaan yang berkaitan dengan harga saham yang dapat menumbuhkan sinyal yang positif dalam membuka peluang investasi. Penelitian ini bertujuan untuk mengetahui pengaruh kebijakan dividen, keputusan investasi, ukuran perusahaan dan kepemilikan manajerial terhadap nilai perusahaan sektor industri barang konsumsi di Bursa Efek Indonesia pada tahun 2013-2017. Sampel ditentukan menggunakan metode purposive sampling dengan 11 perusahaan. Selanjutnya data tersebut diolah menggunakan analisis regresi linear berganda. Hasil penelitian menunjukkan bahwa kebijakan dividen dan keputusan investasi memiliki pengaruh yang positif dan signifikan terhadap nilai perusahaan. Sedangkan ukuran perusahaan dan kepemilikan manajerial memiliki pengaruh yang negatif dan signifikan terhadap nilai perusahaan.

Kata kunci: Kebijakan dividen, keputusan investasi, ukuran perusahaan, kepemilikan manajerial, nilai perusahaan 


\section{PENDAHULUAN}

Era globalisasi membuat persaingan dalam dunia bisnis semakin ketat. Apalagi dalam perkembangannya, setiap lapisan aktivitas bisnis selalu dipengaruhi oleh kondisi ekonomi, politik dan kecanggihan teknologi. Hal ini menyebabkan setiap perusahaan harus memiliki kebijakan yang tepat untuk bertahan di tengah persaingan bisnis guna mencapai tujuan perusahaan. Esana dan Darmawan (2017) berpendapat bahwa tujuan perusahaan terbagi menjadi dua, antara lain tujuan jangka pendek dan tujuan jangka panjang. Tujuan jangka pendek perusahaan berupa perolehan laba yang maksimal, sedangkan tujuan jangka panjangnya adalah untuk meningkatkan nilai perusahaan.

Nilai perusahaan menjadi sesuatu yang tidak dapat terlepas dari perhatian perusahaan dan investor. Sartono (2010) menyatakan bahwa nilai perusahaan adalah nilai jual sebuah perusahaan sebagai suatu bisnis yang sedang beroperasi. Adanya kelebihan nilai jual di atas nilai likuidasi adalah nilai dari organisasi manajemen yang menjalankan perusahaan itu. Melalui nilai perusahaan, para investor bisa mengetahui sejauh mana suatu perusahaan mampu memaksimalkan kemakmuran para pemegang sahamnya. Pencapaian kemakmuran para pemegang saham dapat dilihat dari sejauh mana perusahaan mampu memberikan pengembalian investasi atas dana yang telah diinvestasikan. Jika dana yang dikelola perusahaan dapat dilakukan dengan baik, maka pengelolaan tersebut akan berimbas pada meningkatnya harga saham perusahaan.

Kondisi internal dan eksternal perusahaan dapat menjadi penyebab utama adanya pergerakan nilai saham, baik itu tentang penurunan harga saham maupun peningkatan harga saham. Kondisi eksternal dari pergerakan harga saham menurut Toin dan Sutrisno (2015) dipengaruhi oleh inflasi, nilai kurs, maupun kondisi perekonomian suatu negara. Sedangkan pada kondisi internal, fluktuasi harga saham dapat dipengaruhi oleh segala aktivitas perusahaan untuk menciptakan aliran kas dan operasi perusahaan. Keberadaan harga saham yang tinggi atau mengalami peningkatan memungkinkan perusahaan telah berhasil melakukan proses pengendalian dan pengelolaan dana atau kekayaan perusahaan dengan baik, yang nantinya akan menghasilkan output berupa keuntungan yang maksimal. Adanya pandangan investor yang menganggap bahwa nilai saham yang tinggi akan memberikan tingkat pengembalian yang juga tinggi, maka keberadaan harga saham yang tinggi tersebut akan memberikan rasa puas pada pemegang saham atas dana yang telah diinvetasikan. Sehingga, rasa puas itu akan menunjukkan semakin meningkatnya kesejahteraan para pemegang saham.

Kebijakan dividen merupakan suatu keputusan yang menyangkut tentang apakah pembagian pendapatan perusahaan akan diserahkan kepada pemegang saham dalam bentuk dividen atau digunakan kembali di dalam perusahaan dalam bentuk laba ditahan (Bambang dalam Bansaleng dkk., 2014). Kebijakan dividen merupakan suatu bentuk keputusan yang akan dilaksanakan oleh pihak internal perusahaan dalam menentukan tingkat pengembalian investasi bagi para pemegang saham. Penerimaan dividen yang tinggi oleh investor akan membuat mereka menilai perusahaan tersebut telah mampu menyejahterakan para pemegang sahamnya, sehingga kepercayaan pemegang saham tersebut akan meningkat dan menganggap perusahaan itu layak digunakan sebagai wadah untuk berinvestasi kembali. Hal ini berarti bahwa nilai perusahaan juga akan meningkat seiring dengan kepercayaan serta kenyamanan para pemegang saham setelah memperoleh tingkat pengembalian investasi yang memuaskan. Penelitian yang dilakukan oleh Putra dan Lestari (2016) menyatakan bahwa kebijakan dividen berpengaruh positif terhadap nilai perusahaan. Akan tetapi, penelitian dari Abidin, dkk. (2014) mendapat hasil berbeda yang menyatakan bahwa kebijakan dividen berpengaruh negatif dan signifikan terhadap nilai perusahaan.

Aktivitas perusahaan yang memiliki tujuan untuk meningkatkan keuntungannya adalah bagaimana perusahaan tersebut 
menentukan keputusan investasi. Saat perusahaan mengharapkan profit yang besar di masa yang akan datang dengan cara melakukan pengelolaan dan perputaran dana, maka perusahaan perlu membuat kebijakan yang tepat dan matang agar keputusan investasi tersebut nantinya tidak akan merugikan perusahaan. Hal ini dikarenakan keputusan investasiyang ditetapkan olehperusahaan dapat mempengaruhi persepsi investor terhadap perusahaan tersebut, apakah keputusan investasi yang telah ditetapkan dapat menarik investor untuk menanamkan modalnya atau tidak. Jika keputusan investasi sejalan dengan tujuan perusahaan untuk meningkatkan nilai perusahaan, maka hal itu akan menjadi keuntungan tersendiri bagi perusahaan untuk memperoleh tingkat pengembalian yang besar. Esana dan Darmawan (2017) menyatakan bahwa keputusan investasi tidak memiliki pengaruh terhadap nilai perusahaan. Sebaliknya, Pertiwi, dkk. (2016) menyatakan bahwa adanya pengaruh positif yang signifikan keputusan investasi terhadap nilai perusahaan.

Besar kecilnya perusahaan juga menjadi penentu bagi investor untuk menanamkan modalnya pada suatu perusahaan. Ukuran perusahaan dengan total aset yang cukup besar dapat menarik para investor untuk berinvestasi, yang pada akhirnya akan berimbas pada meningkatnya nilai perusahaan di mata publik. Pengaruh positif ukuran perusahaan terhadap nilai perusahaan dibuktikan pada hasil penelitian dari Mardiyati, dkk. (2015) dan Rudangga dan Sudiarta (2016). Namun demikian, terdapat pula perbedaan hasil penelitian dari Manoppo dan Ari (2016) yang menyatakan bahwa ukuran perusahaan tidak memiliki pengaruh terhadap nilai perusahaan.

Perusahaan go public yang telah terdaftar di BEI membuat kegiatan investasi bukan sebagai kegiatan tertutup dan hanya diketahui dan dimiliki oleh segelintir orang saja. Saat ini, kepemilikan saham perusahaan dapat dilakukan oleh berbagai pihak, baik itu pihak internal maupun pihak eksternal perusahaan. Bahkan, pihak manajemen perusahaan yang memiliki wewenang untuk menjalankan tugasnya sebagai pengelola dan pengatur aktivitas perusahaan juga diperbolehkan untuk ikut serta dalam kepemilikan saham. Pihak manajemen perusahaan ini diberi hak yang sama untuk menjadi investor dan memiliki saham perusahaan selayaknya pemegang saham secara umum. Syafruddin (2006) berpendapat bahwa harapan dari fungsi manajer puncak yang juga sebagai pemilik, atau yang disebut dengan kepemilikan manajerial adalah agar manajer puncak dalam menjalankan aktivitasnya dapat lebih konsisten dengan kepentingan pemegang saham sehingga nilai perusahaan meningkat. Jadi, jika pihak manajerial perusahaan ikut andil dalam kepemilikan saham, maka kemungkinan mereka akan terdorong untuk meningkatkan nilai perusahaan secara lebih baik. Hal ini dikarenakan para manajer puncak tersebut juga ikut mengalami dampak langsung dari kebijakan yang sedang dijalankan perusahaan. Satu hal yang menjadi masalah adalah ketika pihak manajerial yang merangkap sebagai pemegang saham bertindak sesuai kepentingannya sendiri, bukan bertindak sebagai pihak yang bertugas untuk meningkatkan nilai perusahaan. Oleh karena itu, perlu kajian lebih lanjut apakah kepemilikan saham bagi manajerial perusahaan akan memiliki pengaruh atau tidak terhadap peningkatan nilai perusahaan. Benhardy (2018) mengungkapkan bahwa kepemilikan manajerial memiliki pengaruh yang signifikan terhadap nilai perusahaan. Namun Suastini, dkk. (2016) menyatakan bahwa kepemilikan manajerial memiliki pengaruh negatif terhadap nilai perusahaan.

Kebijakan dividen berkaitan dengan pengambilan keputusan perusahaan dalam melakukan pembayaran dividen atas modal yang telah diserahkan investor kepada perusahaan. Adanya pembagian dividen yang tinggi dan konsisten akan menumbuhkan kepercayaan bagi para pemegang saham untuk terus melakukan penanaman modal. Sehingga dari modal yang diperoleh perusahaan, maka pihak manajemen perusahaan dapat melakukan pengelolaan dan pengalokasian dana untuk memperoleh keuntungan. Salah satu aktivitas 
pengalokasian dana tersebut dapat dilakukan dengan cara melakukan pengeluaran modal untuk investasi dana jangka panjang atau biasa disebut dengan keputusan investasi. Keputusan investasi yang tepat akan membuat perusahaan memperoleh keuntungan yang memungkinkan dapat meningkatkan pertumbuhan aset perusahaan. Hal ini dikarenakan aset yang dimiliki perusahaan memiliki keterkaitan dengan ukuran perusahaan. Manoppo dan Arie (2016) berpendapat bahwa aset yang dimiliki perusahaan untuk memenuhi pengelolaan dana dapat mencerminkan ukuran perusahaan. Oleh karena itu, ukuran perusahaan yang besar dianggap dapat meningkatkan nilai perusahaan. Melalui ukuran perusahaan, pihak administrator juga dapat mengambil keputusan atas kepemilikan kekayaannya, salah satunya adalah kepemilikan saham. Salah satu upaya yang dilakukan perusahaan untuk terus mempertahankan kegiatan operasi dan mengembangkan perusahaannya adalah dengan memperbolehkan manajemen perusahaan sebagai pihak yang dibayar jasanya dalam mengelola perusahaan untuk ikut serta dalam kepemilikan saham. Adanya anggapan bahwa pihak agen yang berperan ganda menjadi pemegang saham akan membuat mereka melaksanakan kegiatan operasi dan pengelolaan dana perusahaan secara optimal.

Uraian di atas menunjukkan bahwa adanya kebijakan dividen dalam pemberian laba perusahaan kepada pemegang saham, keputusan-keputusan investasi yang dijalankan perusahaan, besarnya laba atau aktiva yang dimilik perusahaan, hingga adanya pihak manajerial yang merangkap sebagai pemilik saham perusahaan menjadi topik masalah yang perlu dikaji dan diteliti pengaruhnya terhadap peningkatan nilai perusahaan. Melalui penelitian ini, akan diteliti bagaimana kebijakan dividen, keputusan investasi, ukuran perusahaan dan kepemilikan manajerial dijadikan sebagai faktor yang diduga memiliki pengaruh terhadap nilai perusahaan. Selain itu, adanya inkonsistensi atau perbedaan hasil penelitian dari tiap-tiap faktor yang mempengaruhi nilai perusahaan membuat penulis terdorong untuk meneliti pengaruh dari kebijakan dividen, keputusan investasi, ukuran perusahaan dan kepemilikan manajerial terhadap nilai perusahaan. Penelitian ini akan mengambil jangka waktu antara tahun 2013 - 2017 pada laporan tahunan perusahaan yang tersedia di laman website Bursa Efek Indonesia.

Sektor industri barang konsumsi (consumer goods industry sector) di BEI dipilih menjadi objek penelitian karena pada sektor ini terjadi persaingan yang cukup ketat bagi perusahaan untuk menarik minat konsumen dan para investor. Perusahaan yang berada di sektor industri barang konsumsi adalah perusahaan yang menyediakan barang yang banyak digunakan atau dikonsumsi oleh masyarakat untuk kebutuhan sehari-hari. Perusahaan pada sektor tersebut menjadi salah satu pilihan utama bagi investor sehingga investor memiliki fokus yang lebih terhadap perusahaan karena setiap permasalahan yang terjadi pada perusahaan ini, seperti penurunan penjualan, penurunan kualitas produk, kekurangan persediaan, permasalahan limbah dan lainnya dapat mempengaruhi perubahan harga saham perusahaan (Benhardy, 2018).

Berdasarkan uraian di atas, maka peneliti tertarik melakukan penelitian dengan judul "Pengaruh Kebijakan Dividen, Keputusan Investasi, Ukuran Perusahaan dan Kepemilikan Manajerial Terhadap Nilai Perusahaan (Studi kasus pada Sektor Industri Barang Konsumsi di Bursa Efek Indonesia Tahun 2013-2017).”

\section{TINJAUAN PUSTAKA Manajemen Keuangan}

Menurut Sutrisno (2013) manajemen keuangan merupakan segala kegiatan perusahaan yang berkaitan dengan usaha untuk mendapatkan dan mengalokasi dana secara efisien. Sedangkan menurut Mulyawan (2015) manajemen keuangan diartikan sebagai semua kegiatan keuangan yang ada di organisasi, termasuk didalamnya terdapat kegiatan planning, analisis serta pengendalian yang dilakukan oleh manajer keuangan. Sementara itu, Hanafi (2012) menyatakan bahwa manajemen keuangan adalah suatu 
aktivitas perusahaan yang berkaitan dengan kegiatan perencanaan, pengorganisasian, staffing, pelaksanaan, serta pengendalian fungsi-fungsi keuangan.

Berdasarkan tiga pengertian dari para ahli tersebut, maka manajemen keuangan dapat diartikan sebagai segala aktivitas perusahaan yang didalamnya berisi tentang kegiatan perencanaan hingga pengendalian keuangan perusahaan yang dilaksanakan secara efisien guna untuk mencapai tujuan perusahaan, dimana dalam hal ini biasanya menjadi peran seorang manajer keuangan.

\section{Nilai Perusahaan}

Husnan (2004) mendefinisikan nilai perusahaan sebagai suatu harga yang bersedia untuk dibayarkan oleh calon pembeli apabila perusahaan tersebut dijual. Pratiwi (2017) berpendapat bahwa nilai perusahaan sebagai persepsi investor terhadap perusahaan yang berkaitan dengan harga saham. Harga saham yang tinggi akan meningkatkan nilai perusahaan. Oleh karena itu, setiap perusahaan berlomba-lomba untuk meningkat nilai perusahaannya karena nilai yang tinggi akan menunjukkan kemakmuran pemegang saham yang juga tinggi.

Rachman, dkk. (2015) berpendapat bahwa nilai perusahaan akan menggambarkan baik buruknya pengelolaan perusahaan yang dilakukan oleh manajemen. Hal paling penting yang diperhatikan adalah bagaimana pihak manajemen mampu untuk mengelola aset perusahaan yang nantinya akan mempengaruhi pembentukan harga saham. Harga saham yang tinggi akan memunculkan sebuah peluang investasi. Peluang investasi tersebut akan memberikan sinyal yang positif bagi pertumbuhan perusahaan di masa yang akan datang. Sehingga akan meningkatkan harga saham bagi perusahaan, dan dengan meningkatnya harga saham maka nilai perusahaan pun juga ikut meningkat.

Berdasarkan paparan di atas, keberadaan nilai perusahaan memiliki makna sebagai tolok ukur dan pandangan perusahaan bagi investor dan para pemegang saham. Jika investor dan para pemegang saham menilai suatu perusahaan dengan baik, maka hal ini akan memberikan sinyal positif bagi perusahaan untuk membuka peluang investasi.

\section{Teori Persinyalan (Signaling Theory)}

Hartono (2010) menyatakan bahwa sinyal merupakan tindakan yang diambil oleh pihak manajemen perusahaan untuk memberikan informasi kepada pihak investor terkait dengan penilaian prospek perusahaan di masa yang akan datang. Salah satu contohnya adanya informasi penawaran saham perusahaan akan dianggap sebagai sebuah sinyal oleh para pemegang saham tentang kemungkinan adanya keuntungan perusahaan di masa yang akan datang.

Hal yang mendasari adanya teori ini adalah ketidaksamaan informasi yang diterima oleh manajer puncak dan para pemegang saham perusahaan yang biasa disebut dengan asimetri informasi. Terdapat beberapa informasi di perusahaan yang hanya bisa diketahui oleh pihak manajer, tetapi tidak diketahui oleh pemegang saham. Oleh karena itu, perbedaan informasi tersebut dapat membuat adanya perubahan nilai perusahaan atau dengan kata lain telah terdapat sinyal (pertanda) baru (Wongso, 2012).

Berdasarkan penjelasan di atas, teori persinyalan merupakan suatu teori yang bisa menyebabkan adanya perubahan dari nilai perusahaan. Munculnya sinyal yang positif dapat memberikan tanda akan adanya pertumbuhan perusahaan. Sedangkan sinyal yang negatif memungkinkan ada pertanda bahwa perusahaan akan mengalami kerugian di masa yang akan datang.

\section{Teori Kebijakan Dividen}

Syamsudin (2011) menyatakan bahwa dividen adalah suatu pembayaran yang bersifat permanen atas modal yang telah diserahkan oleh pemegang saham atau pemilik perusahaan. Kebijakan dividen menurut Mulyawan (2015) merupakan suatu kebijakan untuk membagikan laba perusahaan kepada para pemegang saham dalam bentuk dividen atau justru menahannya dalam bentuk laba ditahan yang kemudian digunakan kembali sebagai investasi pada masa yang akan datang. Kebijakan dividen merupakan aksi perusahaan yang perlu dilaksanakan perusahaan karena 
kebijakan ini menyangkut banyaknya keuntungan para pemegang saham saat melakukan investasi. Keuntungan yang diperoleh pemegang saham ini akan berkaitan dengan tujuan utama perusahaan yakni untuk meningkatkan kesejahteraan para pemegang saham (Sumarsono, 2012).

Berdasarkan pengertian di atas, kebijakan dividen memiliki definisi sebagai penentu kesejahteraan para pemegang saham karena berkaitan dengan kemampuan perusahaan untuk melakukan tingkat pengembalian dana investasi dalam bentuk dividen kepada para pemegang saham maupun dalam bentuk laba ditahan untuk diinvestasikan kembali pada masa yang akan datang. Kebijakan ini menjadi hal penting yang perlu diperhatikan perusahaan karena menyangkut tentang kepentingan para pemegang saham dan manajer perusahaan.

\section{Teori Investasi}

Hartono (2010) mendefinisikan bahwa investasi merupakan penundaan konsumsi selama periode tertentu dengan harapan mendapatkan keuntungan di masa yang akan datang. Adapun Tandelilin (2010) menganggap investasi sebagai komitmen atas sejumlah dana atau sumber daya lainnya yang dilakukan pada saat ini dengan tujuan untuk memperoleh sejumlah keuntungan di masa yang akan datang.

Pada teori investasi, terdapat dua macam tipe investasi yang dilakukan oleh investor yaitu investasi langsung dan investasi tidak langsung. Investasi langsung merupakan pembelian aktiva perusahaan tanpa melalui perantara dengan melakukan pembelian di pasar uang, pasar modal, maupun pasar turunan. Sedangkan aktiva tidak langsung merupakan pembelian aktiva perusahaan dalam bentuk surat-surat berharga dari perusahaan investasi yang menyediakan jasa keuangan untuk publik (Tandelilin, 2010).

\section{Keputusan Investasi}

PujiatidanWidanar(dalamPertiwidkk., 2016) berpendapat bahwa keputusan investasi menyangkut tentang tindakan mengeluarkan dana saat ini sehingga diharapkan di masa yang akan datang bisa mendapatkan arus kas dengan jumlah yang lebih besar daripada dana yang dikeluarkan pada saat ini, sehingga harapan perusahaan untuk selalu berkembang akan semakin terencana. Keputusan investasi dimulai dengan indentifikasi peluang investasi, yang sering disebut dengan proyek investasi modal. Manajer keuangan harus membantu perusahaan mengidentifikasi proyek-proyek yang menjanjikan dan memutuskan berapa banyak akan diinvestasikan dalam tiap proyek (Mulyawan, 2015).

Sutrisno (2013) menyatakan bahwa suatu keputusan investasi mempunyai dimensi waktu yang panjang, sehingga sangat perlu dilakukan pertimbangan dengan baik. Keputusan investasi ini sering juga disebut sebagai capital budgeting yakni keseluruhan proses perencanaan dan pengambilan keputusan mengenai pengeluaran dana yang jangka waktu kembalinya dana tersebut melebihi satu tahun satu tahun atau berjangka panjang.

Berdasarkan pendapat tersebut, keputusan investasi merupakan suatu tindakan untuk menentukan pengelolaan dana dengan jangka waktu yang cukup lama, sehingga manajer keuangan yang akan memutuskan untuk melakukan perputaran dana harus merencanakan dan membuat pertimbangan yang terbaik agar di masa yang akan datang tidak merugikan perusahaan.

\section{Ukuran Perusahaan}

Riyanto (1995) menyatakan bahwa ukuran perusahaan merupakan besar kecilnya perusahaan yang dilihat dari besarnya nilai ekuitas, nilai perusahaan, ataupun hasil nilai total aktiva dari suatu perusahaan. Ukuran perusahaan dapat dilihat dari total aset yang dimiliki perusahaan yang dapat digunakan untuk kegiatan perusahaan. Perusahaan dengan aset yang besar akan lebih memudahkan manajer keuangan dalam menggunakan aset perusahaan, jika dilihat dari sisi manajer yang akan memudahkannya untuk mengendalikan perusahaan guna meningkatkan nilai perusahaan (Abidin dkk., 2014).

Pramesti, dkk. (2014) berpendapat bahwa aktiva biasanya menjadi tolok ukur besar tidaknya suatu perusahaan. Perusahaan 
besar biasanya mempunyai aktiva yang juga besar. Secara teoretis, perusahaan yang besar akan mempunyai kepastian yang lebih besar daripada perusahaan kecil sehingga akan mengurangi tingkat ketidakpastian investasi. Hal ini dapat membantu investor untuk memprediksi risiko yang akan didapatkan ketika memutuskan untuk berinvestasi pada perusahaan tersebut.

Berdasarkan pengertian di atas, dapat disimpulkan bahwa ukuran perusahaan merupakan suatu indikator untuk menilai perusahaan dengan cara melihat dari besar kecilnya aset yang dimiliki perusahaan, termasuk di dalamnya tentang bagaimana kemampuan perusahaan untuk mengelola dana atau kekayaan yang dimilikinya dalam memperoleh keuntungan guna menyejahterakan para pemegang saham.

\section{Teori Agensi (Agency Theory)}

Jensen \& Meckling (dalam Fadah, 2009) mendefiniskan hubungan keagenan sebagai sebuah kontrak terhadap para agen atau pihak yang diambil jasanya untuk melaksanakan dan menjalankan kegiatan yang ada dalam perusahaan. Wewenang yang didelegasikan pada agen tersebut adalah berupa hak untuk membuat keputusan yang menguntungkan perusahaan. Akan tetapi masalah akan timbul pada pendelegasian tugas kepada agen jika mereka memiliki kepentingan terhadap insentif yang akan mereka terima, disamping kewajiban mereka bertugas untuk memaksimumkan kesejahteraan pemilik saham perusahaan.

Teori agensi adalah teori yang menjelaskan hubungan pemegang saham dengan agen atau pihak yang diberi tugas untuk mengelola perusahaan. Agen ini merupakan tenaga profesional yang akan menjalankan operasional dan mengambil alih untuk mengatur aktivitas perusahaan dengan tujuan untuk meningkatkan keuntungan perusahaan. Adanya seorang agen menyebabkan terpisahnya dua kelompok berkepentingan di dalam perusahaan, yaitu antara kelompok pemegang saham dan agen itu sendiri. Pemegang saham memiliki hak untuk mendapatkan dividen atas pengelolaan dana yang sudah diserahkan kepada perusahaan. Sedangkan agen memiliki hak untuk mendapatkan insentif sebagai balas jasa saat menjalankan tugas yang sesuai dengan kepentingan perusahaan (Rachman dkk., 2015).

Brigham dan Houston (2006) menyatakan bahwa teori keagenan dijadikan sebagai dasar perspektif untuk memahami tentang proses pengelolaan perusahaan serta menjelaskan hubungan antara pihak manajemen (agen) dan pemegang saham. Hubungan agen terjadi ketika seseorang atau lebih menyewa individu lain atau organisasi untuk melakukan sejumlah jasa dan melimpahkan kewenangan untuk membuat keputusan kepada agen tersebut.

Berdasarkan beberapa pengertian tentang teori keagenan tersebut, maka dapat diketahui bahwa agen merupakan suatu pihak yang memiliki tugas utama untuk mengatur dan mengelola kegiatan perusahaan, dimana pihak ini memiliki kepentingan yang berbeda dengan pemegang saham. Tugas yang diberikan kepada agen tersebut memiliki tujuan untuk meningkatkan nilai perusahaan, dan sebagai imbalan atas pelaksanaan tugasnya,maka agen memiliki hak untuk mendapatkan insentif atas perannya yang telah memaksimalkan profit perusahaan.

\section{Kepemilikan Manajerial}

Bodie (2006) mendefinisikan kepemilikan manajerial merupakan bentuk pemisahan kekayaan antara pihak internal dan eksternal perusahaan. Para pemegang saham yang terdiri atas beberapa individu atau kelompok yang berbeda membuat perusahaan membutuhkan dewan komisaris untuk mengawasi kegiatan perusahaan. Struktur kepemilikan tersebut mendefiniskan bahwa adanya perbedaan antara pemilik dan manajer perusahaan sebagai pelaksana kegiatan. Oleh karena itu, adanya perbedaan kepemilikan ini dapat memberi stabilitas bagi perusahaan yang tidak dimiliki oleh perusahaan dengan pemilik merangkap manajer.

Salah satu upaya untuk mengurangi terjadinya agency problem antara pihak agen dan pihak pemegang saham adalah pemberian 
insentif pada manajer sekaligus memberi kesempatan pada manajer tersebut untuk ikut serta dalam kepemilikan saham perusahaan. Adapun pihak manajerial yang dimaksud disini adalah termasuk direktur dan komisaris yang memiliki keterlibatan secara langsung dalam proses pengambilan keputusan perusahaan (Fadah, 2008).

Kepemilikan manajerial memiliki kaitan erat dengan saham yang dimiliki oleh para manajer perusahaan. Pengambilan keputusan perusahaan perlu dilakukan oleh seorang manajer untuk meningkatkan keuntungan perusahaan. Manajer yang sekaligus menjadi pemegang saham akan berusaha untuk meningkatkan nilai perusahaan, karena jika nilai perusahaan bertambah maka tingkat pengembalian yang mereka dapatkan juga tinggi. (Brigham dan Houston, 2011; Dewi dkk., 2018).

Berdasarkan pengertian di atas, kepemilikan manajerial merupakan suatu hal yang tidak dapat dipisahkan antara kepentingan manajer, pemegang saham dan perusahaan. Seorang manajer yang kemudian juga berperan sebagai pemegang saham perusahaan akan berpengaruh terhadap tindakan mereka saat melaksanakan kebijakan perusahaan. Hal ini dikarenakan para manajer tersebut akan berusaha untuk meningkatkan keuntungan perusahaan. Ketika perusahaan mengalami pertambahan kekayaan, maka nilai perusahaan akan ikut meningkat yang akan berujung pada meningkatnya tingkat pengembalian yang akan diperoleh oleh para pemegang saham.

\section{Kerangka Konseptual}

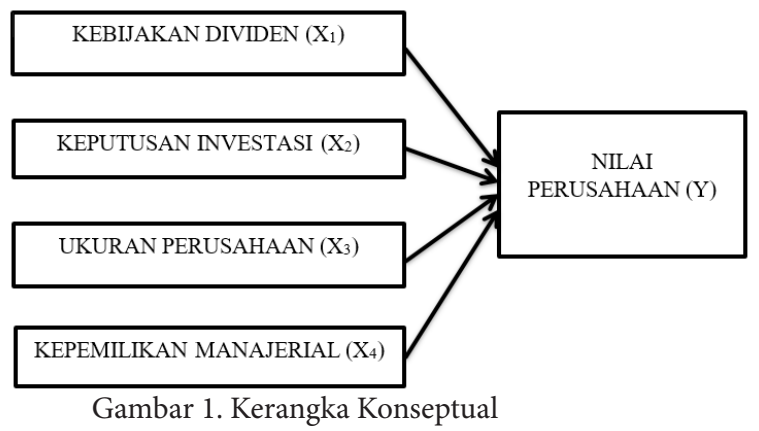

\section{Hipotesis}

Pada penelitian ini, hipotesis yang akan diuji adalah :
H1 : Kebijakan dividen berpengaruh positif dan signifikan terhadap nilai perusahaan H2 : Keputusan investasi berpengaruh positif dan signifikan terhadap nilai perusahaan H3 : Ukuran perusahaan berpengaruh positif dan signifikan terhadap nilai perusahaan H4 :Kepemilikan manajerial berpengaruh positif dan siginifikan terhadap nilai perusahaan

\section{METODE PENELITIAN}

Jenis penelitian ini adalah jenis penelitian eksplanatori (explanatory research), yaitu penelitian yang menunjukkan hubungan kausal dari kemungkinan adanya hubungan sebab-akibat antar variabel-variabel penelitian. Penelitian ini termasuk dalam penelitian kuantitatif dengan menggunakan data sekunder yang di ambil dari perusahaan sektor industri barang konsumsi yang terdaftar di BEI pada periode 2013-2017. Adapun populasi dalam penelitian ini meliputi seluruh perusahaan yang ada di sektor industri barang konsumsi yang terdaftar di BEI dengan jumlah keseluruhan 35 perusahaan. Setelah populasi penelitian diketahui, maka peneliti menggunakan metode pengampilan sampel yang bersifat tidak acak, yaitu menggunakan metode purposive sampling yang dapat dilihat pada tabel berikut :

Penelitian ini menggunakan data sekunder yang diambil dari website resmi BEI yaitu www.idx.co.id. Sektor industri barang konsumsi dipilih menjadi objek penelitian dengan mengambil informasi mengenai laporan keuangan perusahaan yang terpada sektor tersebut. Dari masing-masing data laporan tahunan perusahaan, maka dikumpulkan sejumlah data yang berhubungan dengan pengukuran kebijakan dividen, keputusan investasi, ukuran perusahaan, kepemilikan manajerial, serta nilai perusahaan. Untuk melakukan analisis data, penulis menggunakan analisis regresi linear berganda dengan alat bantu IBM SPSS ${ }^{\mathrm{TM}}$ Statistics versi 22. Analisis regresi linear berganda berfungsi untuk menghitung besarnya pengaruh dua atau lebih variabel bebas terhadap variabel terikat juga untuk memprediksi pengaruh 
Tabel 1. Kriteria Penentuan Sampel

\begin{tabular}{lc}
\hline \multicolumn{1}{c}{ KETERANGAN } & JUMLAH \\
\hline $\begin{array}{l}\text { Perusahaan sektor industri barang konsumsi yang } \\
\text { terdaftar di BEI tahun 2013-2017 }\end{array}$ & 35 \\
Perusahaan sektor industri barang konsumsi yang tidak \\
aktif mencatatkan sahamnya di Bursa Efek Indonesia \\
selama periode penelitian \\
$\begin{array}{l}\text { Perusahaaan sektor industri barang konsumsi yang tidak } \\
\text { mempublikasikan annual report secara lengkap selama } \\
\text { periode penelitian dari tahun 2013-2017 } \\
\text { Perusahaan sektor industri barang konsumsi yang tidak } \\
\text { memberikan informasi lengkap mengenai indikator- } \\
\text { indikator yang digunakan untuk menjelaskan variabel } \\
\text { dalam penelitian ini. } \\
\text { Jumlah Sampel Perusahaan }\end{array}$ \\
\hline
\end{tabular}

variabel terikat tersebut terhadap dua atau lebih variabel bebas sebelumnya.

Definisi Operasional Variabel dan Skala Pengukuran

Adapun variabel-variabel yang digunakan dalam penelitian ini antara lain :

1) Variabel Independen

Pada penelitian ini, peneliti menetapkan empat variabel independen yang akan diuji pengaruhnya terhadap variabel dependen meliputi :

a. Kebijakan Dividen

Rasio pengukuran yang digunakan untuk menghitung kebijakan dividen adalah Dividen Payout Ratio (DPR). DPR merupakan rasio pengukuran yang membandingkan antara pembayaran laba perusahaan pada pemegang saham dengan jumlah lembar saham yang dimiliki pada perusahaan.

Senata (2016) menyebutkan bahwa pengukuran kebijakan dividen menggunakan DPR diukur dengan rumus :

$$
\mathrm{DPR}=\frac{\text { Dividend Per Share }}{\text { Earning Per Share }}
$$

b. Keputusan Investasi

Pertiwi dkk. (2016) mengukur keputusan investasi dengan menggunakan Price Earning Ratio (PER) dengan rumus : PER $=$ Harga Per Lembar Saham Laba Per Lembar Saham

c. Ukuran Perusahaan

Jogiyanto (2008) mengukur ukuran perusahaan menggunakan rumus : Size $=$ Ln (Total Aset)

d. Kepemilikan Manajerial

$$
\text { Hariyanto dan Lestari }
$$
mengukur kepemilikan manajerial (KM) dengan menggunakan rumus sebagai berikut :

$$
\mathrm{KM}=\frac{\text { Jumlah saham manajerial }}{\text { Jumlah saham yang beredar }} \times 100 \%
$$

2) Variabel Dependen

Pada penelitian ini, yang menjadi variabel dependen dalam penelitian adalah nilai perusahaan. Kasmir (dalam Prastuti dan Sudiartha, 2016) mengungkapkan bahwa nilai perusahaan dapat dihutung menggunakan Price Book Value (PBV). PBV merupakan rasio antara harga perlembar saham dengan nilai buku perlembar saham. Esana dan Darmawan (2017) melakukan pengukuran nilai perusahaan menggunakan PBV dengan rumus :$$
\mathrm{PBV}=\frac{\text { Market price per share }}{\text { Book value per share }}
$$ \\ Metode Analisis Data dan Pengujian Hipotesis}

Analisis data yang dimaksud dalam penelitian ini meliputi:

a. Analisis Statistik Deskriptif

Statistik deskriptif merupakan statistik yang berguna untuk memberikan gambaran terhadap objek penelitian tanpa harus memberikan kesimpulan yang berlaku secara umum. Data-data yang akan dihasilkan pada 
analisis ini meliputi mean, standar deviasi, variansi, maksimum, minimum dan range dari variabel yang telah diolah.

b. Uji Asumsi Klasik

Ada empat macam uji asumsi klasik yang keempatnya memiliki fungsi yang berbeda-beda antara lain :

1) Uji Normalitas

Uji normalitas ini menggunakan uji statistik nonparametrik kolmgrov-smirnov (KS), yaitu dengan kriteria pengujian signifikansi 0,05 . Uji normalitas berguna ini untuk menguji residual apakah terdistribusi secara normal dengan signifikansi $>0,05$ atau terdistribusi secara tidak normal dengan signifikansi $<0,05$ 2) Uji Heteroskedastisitas

Uji heteroskedastisitas menggunakan signifikansi $>0,05$ untuk menyatakan suatu data dtidak mengalami heteroskedastisitas. Uji ini dilakukan untuk mendeteksi apakah terjadi ketidaksamaan varians dari residual suatu pengamatan ke pengamatan yang lain.

3) Uji Autokorelasi

Pengujian autokorelasi menggunakan uji Durbin-Watson (DW), dimana jika hasil pengujian nilai data mendekati 2 , maka data tersebut dinyatakan tidak ada autokorelasi.

4) Uji Multikolinearitas

Uji multikolinearitas dapat dilihat dari nilai tolerance dan variance inflation factor (VIF), dimana hasil uji data dinyatakan tidak mengalami multikolinearitas apabila nilai tolerance menunjukkan $>0.1$ atau sama dengan nilai $\mathrm{VIF}<10$.

\section{c. Analisis Regresi Linear Berganda}

Model persamaan regresi linear berganda yang dilakukan dalam penelitian ini adalah sebagai berikut:

$$
\mathrm{Y}=\alpha+\mathrm{b}_{1} \mathrm{X}_{1}+\mathrm{b}_{2} \mathrm{X}_{2}+\mathrm{b}_{3} \mathrm{X}_{3}+\mathrm{b}_{4} \mathrm{X}_{4}+\mathrm{e}
$$

Keterangan :

$$
\begin{aligned}
& \mathrm{Y} \quad=\text { Nilai perusahaan } \\
& \alpha \quad=\text { Nilai konstanta } \\
& \mathrm{b}_{1}, \mathrm{~b}_{2}, \mathrm{~b}_{3} \quad=\text { Koefisien regresi } \\
& \mathrm{X}_{1} \quad=\text { Kebijakan dividen } \\
& \mathrm{X}_{2} \quad=\text { Keputusan investasi } \\
& \mathrm{X}_{3} \quad=\text { Ukuran perusahaan } \\
& \mathrm{X}_{4} \quad=\text { Kepemilikan manajerial } \\
& \text { e } \quad=\text { Standar error }
\end{aligned}
$$

1) Koefisien Determinasi

Besaran dari koefisien determinasi atau $\mathrm{R}^{2}$ adalah $0<\mathrm{R}^{2}<1$. Semakin besar koefisien determinasi dalam penelitian (mendekati 1), maka semakin baik hasil dari model regresi. Sebaliknya, koefisien determinasi yang kecil (mendekati 0) maka akan semakin terbatas model regresi variabel independen untuk memberikan informasi dalam memprediksi variabel dependen..

2) Uji $F$

Uji $F$ berfungsi untuk mengetahui pengaruh variabel independen terhadap dependen, apakah memiliki pengaruh atau tidak berpengaruh secara simultan. Uji hipotesis ini menggunakan taraf kepercayaan sebesar $5 \%$ atau 0,05 . Jika hasil perhitungan uji $\mathrm{F}$ lebih besar dari nilai $\mathrm{F}$ di dalam tabel maka variabel dependen dinyatakan memiliki pengaruh yang signifikan terhadap variabel dependen..

3) Uji t

Uji $t$ berguna untuk signifikansi pengaruh variabel independen terhadap variabel dependen secara parsial. Uji hipotesis ini menggunakan taraf signifikansi sebesar 5\% atau 0,05 . Jika hasil perhitungan uji t memiliki nilai lebih kecil dari taraf signifikansi maka dapat dikatakan bahwa variabel independen memiliki pengaruh secara parsial terhadap

Tabel 2. Statistik Deskriptif

\begin{tabular}{lrrrrrr}
\hline & N & \multicolumn{1}{c}{ Range } & Minimum & Maximum & Mean & Std. Deviation \\
\hline Y & 55 & 81,82 &, 62 & 82,44 & 10,0715 & 15,89182 \\
X1 & 55 & 99,81 &, 08 & 99,89 & 55,5585 & 27,49448 \\
X2 & 55 & 60,54 &, 35 & 60,89 & 22,4271 & 15,16043 \\
X3 & 55 & 4,97 & 13,37 & 18,34 & 15,6713 & 1,63671 \\
X4 & 55 & 80,99999 &, 00001 & 81,00000 & 14,3128455 & 25,70546433 \\
\hline Valid N (listwise) & 55 & \multicolumn{7}{c}{} \\
\hline
\end{tabular}


Tabel 3 Uji Normalitas

\begin{tabular}{llr}
\hline & & $\begin{array}{c}\text { Unstandardized } \\
\text { Residual }\end{array}$ \\
\hline $\mathrm{N}$ & Mean & 55 \\
Normal Parametersa,b & Std. Deviation &, 0000000 \\
& Absolute & 1,34945768 \\
Most Extreme Differences & Positive &, 113 \\
& Negative &, 113 \\
Test Statistic & &,- 094 \\
\hline Asymp. Sig. (2-tailed) & &, 113 \\
\hline Sumber : data diolah, 2019 & &, $075^{\mathrm{c}}$ \\
\hline
\end{tabular}

Tabel 4. Ringkasan Uji Heteroskedastisitas

\begin{tabular}{lllll}
\hline Keterangan & Signifikansi & Alpha & Kondisi & Simpulan \\
\hline Kebijakan Dividen & 0,942 & 0,05 & Sig. > Alp & Terima Ho \\
Keputusan Investasi & 0,865 & 0,05 & Sig. > Alp & Terima Ho \\
Ukuran Perusahaan & 0,616 & 0,05 & Sig. > Alp & Terima Ho \\
Kepemilikan Manajerial & 0,931 & 0,05 & Sig. > Alp & Terima Ho \\
\hline
\end{tabular}

Tabel 5. Uji Autokorelasi

\begin{tabular}{|c|c|c|c|c|c|}
\hline Model & $\mathrm{R}$ & R Square & $\begin{array}{l}\text { Adjusted R } \\
\text { Square }\end{array}$ & $\begin{array}{l}\text { Std. Error of the } \\
\text { Estimate }\end{array}$ & Durbin-Watsor \\
\hline 1 &, $662^{a}$ & , 438 & ,393 & 1,40240 & 1,772 \\
\hline
\end{tabular}

variabel dependen.

\section{HASIL DAN PEMBAHASAN}

a. Statistik Deskriptif

Dapat dilihat pada tabel 2.

b. Uji Asumsi Klasik

1) Uji normalitas

Tabel 3 menunjukkan bahwa hasil uji normalitas menunjukkan taraf signifikansi sebesar 0,075, dimana nilai Asymp. Sig. (2-tailed) $>$ alpha yang ditetapkan sebesar 5\% atau 0,05 . Hal ini berarti bahwa nilai residu terdistribusi secara normal.

2) Uji Heteroskedastisitas

Tabel 4 menunjukkan bahwa hasil uji heteroskedastisitas masing-masing variabel memiliki taraf signifikansi $>0,05$ maka keempat variabel penelitian tersebut tidak mengalami gejala heteroskedastisitas.

3) Uji Autokorelasi

Tabel 5. menunjukkan bahwa hasil
Durbin-Watson mencapai 1,772. Berdasarkan tabel Durbin-Watson diketahui $\mathrm{d}_{\mathrm{u}}=1,7240$. Merujuk pada rumus $\mathrm{d}_{\mathrm{u}}<\mathrm{d}<4-\mathrm{d}_{\mathrm{u}}$ atau dengan angka $1,7240<1,772<2,276$. Maka data disimpulkan tidak ada serial autokorelasi baik positif maupun negatif

4) Uji Multikolinearitas

Tabel 6 menunjukkan bahwa seluruh variabel penelitian menunjukkan nilai tolerance dengan angka $>0,1$ dan nilai VIF $<10$. Sehingga dapat disimpulkan bahwa data tidak mengalami multikolinearitas.

c. Analisis Regresi Linear Berganda Keterangan :

a. Nilai konstanta (B) bernilai positif sebesar 9,950. Hal ini dapat diartikan bahwa perwujudan nilai perusahaan akan tetap terjadi sebesar 9,950 walaupun seluruh variabel kebijakan dividen $\left(\mathrm{X}_{1}\right)$, keputusan investasi $\left(\mathrm{X}_{2}\right)$, ukuran perusahaan $\left(\mathrm{X}_{3}\right)$ dan kepemilikan manajerial $\left(\mathrm{X}_{4}\right)$ tidak memiliki pengaruh, atau 
Tabel 6. Uji Multikolinearitas

\begin{tabular}{llrr}
\hline & & \multicolumn{2}{c}{ Collinearity Statistics } \\
\cline { 3 - 4 } Model & & Tolerance & \multicolumn{1}{c}{ VIF } \\
\hline 1 & (Constant) & & \\
& KEB. DIVIDEN &, 738 & 1,355 \\
& KEP. INVESTASI &, 830 & 1,205 \\
& UKURAN PERUSAHAAN &, 586 & 1,708 \\
& KEP. MANAJERIAL &, 633 & 1,579 \\
\hline
\end{tabular}

Sumber : data diolah, 2019

Tabel 7. Analisis Regresi Linear Berganda

\begin{tabular}{|c|c|c|c|c|c|c|}
\hline \multirow[b]{2}{*}{ Model } & & \multicolumn{2}{|c|}{ Collinearity Statistics } & \multicolumn{2}{|l|}{$\begin{array}{c}\text { Standardized } \\
\text { Coefficients }\end{array}$} & \multirow[b]{2}{*}{ Sig. } \\
\hline & & Tolerance & VIF & Beta & $\mathrm{T}$ & \\
\hline \multirow[t]{5}{*}{$\overline{1}$} & (Constant) & & & & 2,179 & ,034 \\
\hline & KEB. DIVIDEN & ,738 & 1,355 & ,457 & 3,705 & 001 \\
\hline & KEP. INVESTASI & 830 & 1,205 & ,314 & 2,694 & 010 \\
\hline & UKURAN PERUSAHAAN &, 586 & 1,708 &,- 308 & $-2,222$ & 031 \\
\hline & KEP. MANAJERIAL & 633 & 1,579 &,- 529 & $-3,971$ &, 000 \\
\hline
\end{tabular}

Tabel 8. Uji Koefisien Determinasi

\begin{tabular}{lccccc}
\hline Model & $\mathrm{R}$ & R Square & $\begin{array}{c}\text { Adjusted R } \\
\text { Square }\end{array}$ & $\begin{array}{c}\text { Std. Error of the } \\
\text { Estimate }\end{array}$ & Durbin-Watson \\
\hline 1 &, $662^{\mathrm{a}}$ &, 438 &, 393 & 1,40240 & 1,772 \\
\hline Sumber : data diolah, 2019 & &
\end{tabular}

seluruh variabel independen yang digunakan dalam penelitian diasumsikan sama dengan nol.

b. Koefisien regresi $\mathrm{X}_{1}$ (kebijakan dividen) bernilai positif $(0,385)$. Hal ini dapat diartikan bahwa terdapat hubungan antara kebijakan dividen dengan nilai perusahaan adalah berbanding lurus atau linier. Apabila kebijakan dividen mengalami kenaikan sebesar 1\% maka nilai perusahaan juga akan meningkat sebesar $38,5 \%$ dengan asumsi variabel lain dianggap konstan.

c. Koefisien regresi $\mathrm{X}_{2}$ (keputusan investasi) bernilai positif $(0,312)$, hal ini dapat diartikan bahwa terdapat hubungan antara keputusan investasi dengan nilai perusahaan berbanding lurus atau linier. Apabila keputusan investasi mengalami kenaikan sebesar $1 \%$ maka nilai perusahaan juga akan meningkat sebesar $31,2 \%$ satuan dengan asumsi variabel lain dianggap konstan.

d. Koefisien regresi $\mathrm{X}_{3}$ (ukuran perusahaan) bernilai negatif $(-2,693)$, hal ini dapat diartikan bahwa terdapat hubungan antara ukuran perusahaan dengan nilai perusahaan yang berbanding terbalik. Apabila ukuran perusahaan mengalami kenaikan sebesar $1 \%$, maka nilai perusahaan akan mengalami penurunan sebesar 269,3\% satuan dengan asumsi variabel lain dianggap konstan.

e. Koefisien regresi $\mathrm{X}_{4}$ (kepemilikan manajerial) bernilai negatif $(-0,327)$, hal ini dapat diartikan bahwa terdapat hubungan antara ukuran perusahaan dengan nilai perusahaan yang berbanding terbalik. Apabila variabel kepemilikan manajerial meningkat sebesar 1\%, maka nilai perusahaan akan mengalami penurunan sebesar $32,7 \%$ satuan dengan asumsi variabel lain dianggap konstan.

1) Uji Koefisien Determinasi

Tabel 8 menunjukkan bahwa nilai $\mathrm{R}$ Square sebesar 0,438 menunjukkan bahwa 43,8\% variasi dari variabel dependen dipengaruhi secara bersama-sama oleh 
Tabel 9. Uji F

\begin{tabular}{lllllll}
\hline \multicolumn{2}{l}{ Model } & Sum of Squares & Df & Mean Square & F & Sig. \\
\hline $1 \quad$ Regression & 76,530 & 4 & 19,133 & 9,728 &, $000^{\text {b }}$ \\
& Residual & 98,336 & 50 & 1,967 & & \\
\multicolumn{2}{l}{ Total } & 174,866 & 54 & & & \\
\hline \multicolumn{2}{l}{ Sumber : data diolah, 2019 }
\end{tabular}

Tabel 10 Uji t

\begin{tabular}{llrr}
\hline Model & & T & Sig. \\
\hline 1 & (Constant) & 2,179 &, 034 \\
& KEB. DIVIDEN & 3,705 &, 001 \\
& KEP. INVESTASI & 2,694 &, 010 \\
& UKURAN PERUSAHAAN & $-2,222$ &, 031 \\
& KEP. MANAJERIAL & $-3,971$ &, 000 \\
\hline
\end{tabular}

Sumber : data diolah, 2019

variabel kebijakan dividen $\left(\mathrm{X}_{1}\right)$, keputusan investasi $\left(\mathrm{X}_{2}\right)$, ukuran perusahaan $\left(\mathrm{X}_{3}\right)$ dan kepemilikan manajerial $\left(\mathrm{X}_{4}\right)$. Sementara $56,2 \%$ dipengaruhi oleh variabel lain yang tidak digunakan dalam penelitian. Selain itu, Standard error of estimates (SEE) yang menunjukkan nilai sebesar 1,40240 memilik arti bahwa semakin kecil nilai SEE maka akan membuat model regresi semakin tepat untuk memprediksi variabel dependen.

2) Uji F

Berdasarkan tabel 9 dapat dilihat bahwa diperoleh $\mathrm{F}_{\text {hitung }}$ sebesar 9,728, dengan probabilitas 0,000 . Karena nilai probabilitas jauh lebih kecil dari 0,05 dan $\mathrm{F}_{\text {hitung }}$ lebih besar dari $\mathrm{F}_{\text {tabel }}(9,728>2,56)$ maka dapat disimpulkan bahwa koefisien regresi pada variabel independen secara simultan berpengaruh terhadap nilai perusahaan.

3) Uji t

Tabel 10 menunjukkan bahwa variabel kebijakan dividen, keputusan investasi, ukuran perusahaan dan kepemilikan manajerial menghasilkan perhitungan sebagai berikut :

a) Variabel kebijakan dividen menunjukkan nilai signifikansi sebesar 0,001 , yang mana nilai tersebut jauh lebih kecil dari taraf signifikansi yang telah ditentukan sebesar 0,05 . Adapun nilai $\mathrm{t}$ hitung menunjukkan angka 3,705 dimana angka tersebut lebih besar dari t tabel $(\mathrm{df}=\mathrm{n}-\mathrm{k})$ yakni 1,675 . Sehingga dapat disimpulkan bahwa kebijakan dividen memiliki pengaruh yang positif dan signifikan terhadap nilai perusahaan.

b) Variabel keputusan investasi menunjukkan nilai signifikansi sebesar 0,010 , yang mana nilai tersebut jauh lebih kecil dari taraf signifikansi yang telah ditentukan sebesar 0,05 . Adapun nilai $t$ hitung menunjukkan angka 2,694 dimana angka tersebut lebih besar dari t tabel $(\mathrm{df}=\mathrm{n}-\mathrm{k})$ yakni 1,675 . Sehingga dapat disimpulkan bahwa keputusan investasi memiliki pengaruh yang positif dan signifikan terhadap nilai perusahaan.

c) Variabel ukuran perusahaan menunjukkan nilai signifikansi sebesar 0,031 , yang mana nilai tersebut jauh lebih kecil dari taraf signifikansi yang telah ditentukan sebesar 0,05 . Adapun nilai $\mathrm{t}$ hitung menunjukkan angka 2,222 dimana angka tersebut lebih besar dari t tabel ( $d f=n-k)$ yakni 1,675. Sehingga dapat disimpulkan bahwa ukuran perusahaan memiliki pengaruh yang negatif dan signifikan terhadap nilai perusahaan.

d) Variabel kepemilikan manajerial menunjukkan nilai signifikansi sebesar 0,000, yang mana nilai tersebut jauh lebih kecil dari taraf signifikansi yang telah ditentukan sebesar 0,05 . Adapun nilai thitung menunjukkan angka 3,971 dimana angka tersebut lebih besar dari t tabel $(\mathrm{df}=\mathrm{n}-\mathrm{k})$ yakni 1,675. Sehingga dapat disimpulkan bahwa kepemilikan manajerial memiliki pengaruh yang negatif signifikan terhadap nilai perusahaan.

\section{Pembahasan}

Hasil uji regresi linier berganda 
menunjukkan bahwa variabel kebijakan dividen $\left(\mathrm{X}_{1}\right)$ memiliki pengaruh yang positif dan signifikan terhadap nilai perusahaan. Dengan demikian, hipotesis yang menyatakan bahwa kebijakan dividen berpengaruh positif dan signifikan terhadap nilai perusahaan $\left(\mathrm{H}_{1}\right)$ diterima. Hal ini menandakan bahwa ketika kebijakan dividen mengalami kenaikan, maka akan berdampak pada semakin meningkatnya nilai perusahaan. Hal ini sesuai dengan teori the bird in the hand yang dikemukakan oleh Gordon dan Lintner, dimana investor lebih menyukai pembagian dividen daripada laba ditahan. Teori ini menyatakan bahwa kebijakan perusahaan dalam melakukan pembagian dividen dapat menjadi suatu pertanda (sinyal) yang baik bagi investor dalam melihat masa depan perusahaan. Besarnya dividen yang dibagikan perusahaan dapat mempengaruhi peningkatan harga saham yang nantinya akan berdampak pada meningkatnya nilai perusahaan (Sitepu dalam Esana dan Darmawan, 2017).

Variabel keputusan investasi menunjukkan bahwa terdapat pengaruh positif dan signifikan terhadap nilai perusahaan. Dengan demikian, hipotesis yang menyatakan bahwa keputusan investasi berpengaruh positif dan signifikan terhadap nilai perusahaan $\left(\mathrm{H}_{2}\right)$ diterima. Hal ini menandakan bahwa ketika keputusan investasi mengalami peningkatan, maka akan berdampak pada semakin meningkatnya nilai perusahaan. Hal ini sesuai dengan teori persinyalan yang menyatakan bahwa adanya pengeluaran investasi akan memberikan pertanda positif bagi pertumbuhan perusahaan di masa yang akan datang. Dengan adanya investasi yang dilakukan perusahaan, maka perusahaan tersebut dapat meningkatkan harga saham yang berujung dengan ikut meningkatnya nilai perusahaan (Wahyudi dan Prawestri, 2006).

Variabel ukuran perusahaan menunjukkan bahwa terdapat pengaruh negatif dan signifikan terhadap nilai perusahaan. Dengan demikian, hipotesis yang menyatakan bahwa ukuran perusahaan berpengaruh negatif dan signifikan terhadap nilai perusahaan atau $\left(\mathrm{H}_{3}\right)$ ditolak. Hal ini menandakan bahwa ketika ukuran perusahaan mengalami kenaikan, maka akan berdampak pada semakin menurunnya nilai perusahaan. Kemungkinan suatu perusahaan dengan ukuran yang kecilpun mampu untuk meningkatkan nilai perusahaannya karena perusahaan tersebut tidak perlu menambah jumlah saham yang beredar yang dimungkinkan memiliki risiko tidak pasti di masa depan, sehingga perusahaan tidak perlu berpikir ulang apakah penambahan saham itu akan menguntungkan atau justru merugikan perusahaan.

Variabel kepemilikan manajerial menunjukkan bahwa terdapat pengaruh negatif dan signifikan terhadap nilai perusahaan. Dengan demikian, hipotesis yang menyatakan bahwa kepemilikan manajerial berpengaruh negatif dan signifikan terhadap nilai perusahaan atau $\left(\mathrm{H}_{4}\right)$ ditolak. Hal ini menandakan bahwa ketika kepemilikan manajerial mengalami kenaikan, maka akan berdampak pada semakin menurunnya nilai perusahaan. Teori agensi yang dikemukakan oleh Jensen \& Meckling sejalan dengan hasil penelitian ini dimana teori tersebut menyatakan jika suatu pihak yang diberi wewenang untuk mengelola perusahaan sekaligus sebagai pemilik saham perusahaan, dimungkinkan akan memicu timbulnya agency problem. Fadah (2009) dalam bukunya mengungkapkan bahwa adanya sifat dasar yang dimiliki manusia untuk lebih mendahulukan kepentingan pribadi dibandingkan kepentingan orang lain atau perusahaan, dikhawatirkan akan memunculkan konflik kepentingan.

\section{KESIMPULAN DAN SARAN Kesimpulan}

Berdasarkan hasil analisis data penelitian, maka diketahui bahwa kebijakan dividen dan keputusan investasi terbukti memiliki pengaruh yang positif dan signifikan terhadap nilai perusahaan. Sedangkan pada ukuran perusahaan dan kepemilikan manajerial memiliki pengaruh yang negatif dan signifikan terhadap nilai perusahaan. 11 perusahaan yang menjadi sampel dalam penelitian ini telah melakukan kebijakan pembayaran dividen serta keputusan melakukan pengeluaran 
modal untuk investasi yang tepat untuk meningkatkan nilai perusahaan. Hal ini dapat dilihat dari hasil penelitian yang menunjukkan bahwa kebijakan dividen dan keputusan investasi dapat meningkatkan nilai perusahaan. Sementara itu, perusahaan sampel penelitian diharapkan untuk mempertimbangkan kembali tentang kebijakannya dalam menambah total aset perusahaan serta juga mempertimbangkan adanya kepemilikan saham oleh pihak manajerial. Hal ini disebabkan karena ukuran perusahaan yang besar dan adanya kepemilikan saham oleh pihak manajerial dapat menurunkan nilai perusahaan.

\section{Saran}

1. Bagi pihak perusahaan terutama pada perusahaan di sektor industri barang konsumsi, disarankan untuk memperhatikan segala aspek aktivitas pengelolaan dan pengalokasian dana untuk operasi perusahaan, terutama ketika pihak administrator atau manajemen puncak ingin meningkatkan nilai perusahaannya. Dalam hal ini, variabel yang perlu diperhatikan perusahaan adalah bagaimana kebijakan mereka saat melakukan pengambilan keputusan investasi atau perputaran dana. Investasi yang memiliki dimensi waktu yang panjang dan menyangkut seluruh modal yang dimiliki perusahaan, membuat perusahaan harus melakukan pertimbangan dengan baik sebelum keputusan investasi ditetapkan. Hal tersebut bertujuan untuk menghindari risiko terjadinya kerugian perusahaan di masa yang akan datang.

2. Bagi investor, peneliti menyarankan untuk memperhatikan segala kebijakan perusahaan sebelum mengambil keputusan untuk melakukan investasi atau penanaman modal.

3. Bagi peneliti lain, disarankan untuk menggunakan teknik analisis data dan populasi yang berbeda beserta indikator-indikator lain yang dapat mempengaruhi nilai perusahaan.

\section{REFERENSI}

Abidin, Z., M. W. Yusniar, dan M. Ziyad. 2014. Pengaruh Struktur Modal, Kebijakan Dividen dan Size Terhadap Nilai Perusahaan. Jurnal Wawasan Manajemen. 2(3): 91-102.
Arifin, A. S. 2017. Pengaruh Mekanisme Good Corporate Governance (GCG) dan Kebijakan Hutang Terhadap Nilai Perusahaan di Indonesia Periode 2010-2015. Jurnal Ilmu Manajemen. 5(3): $1-10$.

Sartono. A. R. 2010. Manajemen Keuangan Teori dan Aplikasi. Edisi 4. Yogyakarta : BPFE.

Bansaleng, R. D.V., P. Tommy dan I. S. Saerang. 2014. Kebijakan Hutang, Struktur Kepemilikan dan Profitabilitas Terhadap Kebijakan Dividen Pada Perusahaan Food And Beverage Di Bursa Efek Indonesia. Jurnal EMBA. 2(3): 817-830.

Benhardy, K. A. 2018. Pengaruh Mekanisme Corporate Governance Terhadap Nilai Perusahaan Pada Perusahaan Consumer Goods. Jurnal Manajemen Bisnis dan Kewirausahaan. 3(1): 53-61.

Bodie, K. Alex, M. Alan. 2006. Investments. 6th Edition. Terjemahan oleh Zuliani Dalimunthe dan Budi Wibowo. Investasi. Jakarta : Salemba Empat.

Brealey, R. A., S. C. Myers. dan A. J. Marcus. 2007. Fundamentals Of Corporate Finance. 5th Edition. New York : The McGraw-Hill Companies. Terjemahan oleh Y. A. Zaimur. 2008. Dasar-dasar Manajemen Keuangan Perusahaan. Edisi Kelima. Jakarta : Penerbit Erlangga.

Brigham, E. F. dan J. F. Houston. 2004. Fundamentals of Financial Management. 10th Edition. Singapore : Soth-Western Thomson. Terjemahan oleh A. A. Yulianto. 2006. Dasar-dasar Manajemen Keuangan. Edisi Kesepuluh. Jakarta : Salemba Empat.

Denziana, A. dan W. Monica. 2016. Analisis Ukuran Perusahaan dan Profitabilitas 
Terhadap Nilai Perusahaan. Jurnal Akuntansi \& Keuangan. 7(2): 241-254.

Dewi, A. I. Y. M. dan G. M. Sudiartha. 2017. Pengaruh Profitabilitas, Ukuran Perusahaan, dan Pertumbuhan Aset Terhadap Struktur Modal dan Nilai Perusahaan. E-Jurnal Manajemen UNUD. 6(4): 2222-2252.

Dewi, D. K., A. R. Tanjung, dan N. Indrawati. 2018. Analisis Pengaruh Free Cash Flow Dan Kepemilikan Manajerial Terhadap Nilai Perusahaan dengan Kebijakan Hutang sebagai Variabel Moderating. Jurnal Ekonomi. 26(2): 101-121.

Esana, R. dan A. Darmawan. 2017. Pengaruh Kebijakan Dividen dan Keputusan Investasi Terhadap Nilai Perusahaan serta Dampaknya Terhadap Profitabilitas $\mathrm{t}+1$. Jurnal Administrasi Bisnis (JAB). 50(6): 201-210.

Fadah, I. 2008. Teori dan Aplikasi Kebijakan Dividen Kas dan Biaya Keagenan. Edisi Pertama. Jember : Center For Society Studies.

2009. Manajemen Keuangan Teori dan Aplikasi. Edisi Pertama. Jember : Center For Society Studies.

Fauziah K., Darminto dan R. R. Hidayat. 2014. Pengaruh Dividend Per Share, Return On Asset, dan Debt to Equity Ratio Terhadap Harga Saham. Jurnal Administrasi Bisnis (JAB). 11(1): 1-10.

Febrianti, M. 2012. Faktor-faktor yang Mempengaruhi Nilai Perusahaan pada Industri Pertambangan di Bursa Efek Indonesia. Jurnal Bisnis dan Akuntansi. 14(2): 141-156.

Gayatri, N. L. P. R. dan I. K. Mustanda. 2013. Pengaruh Struktur Modal, Kebijakan Dividen Dan Keputusan Investasi
Terhadap Nilai Perusahaan. Jurnal Fakultas Ekonomi dan Bisnis Universitas Udayana: 1700-1718.

Ghozali, I. 2014. Ekonometrika Teori, Konsep dan Aplikasi dengan IBM SPSS 22. Semarang : Badan Penerbit Universitas Diponegoro.

Hanafi, M. dan A. Halim. 2012. Analisis Laporan Keuangan. Yogyakarta:(UPP) STIM YKPN.

Hariyanto, M. S. dan P. V. Lestari. 2015. Pengaruh Struktur Kepemilikan, IOS, dan ROE Terhadap Nilai Perusahaan pada Perusahaan Food and Beverage. E-Jurnal Manajemen Unud. 4(4): 1599-1626.

Hartono, J. 2010. Teori Portofolio dan Analisis Investasi. Edisi Kelima. Yogyakarta : BPFE.

Hasnawati. 2005. Dampak Set Peluang Investasi Terhadap Nilai Perusahaan Publik di Bursa Efek Jakarta. JAAI. 9(2): 117-126.

Husnan, S. dan E. Pudjiastuti. 1996. Dasar-dasar Manajemen Keuangan. Edisi Pertama. Yogyakarta : UPP AMP YKPN.

Husnan, S. 2001. Manajemen Keuangan Teori dan Penerapan (Keputusan Jangka Pendek). Edisi Keempat. Yogyakarta : BPFE.

Indriyani, E. 2017. Pengaruh Ukuran Perusahaan dan Profitabilitas Terhadap Nilai Perusahaan. Jurnal Ilmu Akuntansi. 10(2): 333-348.

Isbanah, Y. 2015. Pengaruh ESOP, Leverage, And Ukuran Perusahaan Terhadap Kinerja Keuangan Perusahaan di Bursa Efek Indonesia. Journal of Research in Economics And 
Management. 15(1): 28-41.

Lupiyaodi, R. dan R. B. Ikhsan. 2015. Praktikum Metode Riset Bisnis. Jakarta : Salemba Empat.

Manoppo, H. dan F. V. Arie. 2016. Pengaruh Struktur Modal, Ukuran Perusahaan dan Profitabilitas Terhadap Nilai Perusahaan Otomatif yang Terdaftar di Bursa Efek Indonesia Periode 2011-2014. Jurnal EMBA. 4(2): 485-497.

Mardiyati, U., G. N. Ahmad dan M. Abrar. 2015. Pengaruh Keputusan Investasi, Keputusan Pendanaan, Ukuran Perusahaan dan Profitabilitas Terhadap Nilai Perusahaan Pada Sektor Manufaktur Barang Konsumsi Yang Terdaftar di Bursa Efek Indonesia Periode 2010-2013. Jurnal Riset Manajemen Sains Indonesia (JRMSI). 6(1): 417-439.

Mulyawan, S. 2015. Manajemen Keuangan : Pengantar Prof. Dr. H. Moammad Najib. Bandung : Pustaka Setia.

Nazir, M. 2009. Metode penelitian. Jakarta : Penerbit Ghalia Indonesia.

Novari, P. M. dan P. V. Lestari. 2016. Pengaruh Ukuran Perusahaan, Leverage, dan Profitabilitas Terhadap Nilai Perusahaan Pada Sektor Properti dan Real Estate. E-Jurnal Manajemen Unud. 5(9): 5671-5694.

Pertiwi, P. J., P. Tommy, dan J. R. Tumiwa. 2016. Pengaruh Kebijakan Hutang, Keputusan Investasi dan Profitabilitas Terhadap Nilai Perusahaan Food and Beverages yang Terdaftar di Bursa Efek Indonesia. Jurnal EMBA. 4(1): 1369-1380.

Pramesti, A. L. R. dan J. Susilowibowo. 2014. Pengaruh Keputusan Pendanaan
Eksternal, Keputusan Investasi, dan Firm Size Terhadap Nilai Perusahaan. Jurnal Ilmu Manajemen. 2(4): 1416-1432.

Prastuti, N. K. R. dan I. G. M. Sudiartha. 2016. Pengaruh Struktur Modal, Kebijakan Dividen, dan Ukuran Perusahaan Terhadap Nilai Perusahaan pada Perusahaan Manufaktur. E-Jurnal Manajemen Unud. 5(3): 1572-1598.

Pratama, I. G. B. A. dan I. G. B. Wiksuana. 2016. Pengaruh Ukuran Perusahaan Dan Leverage Terhadap Nilai Perusahaan Dengan Profitabilitas Sebagai Variabel Mediasi. E-Jurnal Manajemen Unud. 5(2): 1338-1367.

Pratiwi, R. A. 2017. Pengaruh Good Corporate Governance dan Ukuran Perusahaan Terhadap Nilai Perusahaan pada Perusahaan Food And Beverage yang Listing di Bursa Efek Indonesia. Jom FISIP. 4(2): 1-13.

Priyatno, D. 2011. Buku Saku SPSS. Analisis Statistik Dengan Microsoft Excel \& SPSS. Yogyakarta : Penerbit Andi.

Puspitaningtyas, Z. 2017. Efek Moderasi Kebijakan Dividen dalam Pengaruh Profitabilitas terhadap Nilai Perusahaan Manufaktur. Jurnal Akuntansi, Ekonomi dan Manajemen Bisnis. 5(2): 173-180.

Putra, AA. N. D. A. dan P. V. Lestari. 2016. Pengaruh Kebijakan Dividen, Likuiditas, Profitabilitas dan Ukuran Perusahaan Terhadap Nilai Perusahaan. E-Jurnal Manajemen Unud. 5(7): 4044-4070.

Putri, N.S. dan N. F. Nuzula. 2018. Pengaruh Konsentrasi Kepemilikan Publik Terhadap Investasi Research and Development Serta Dampaknya Terhadap Nilai Perusahaan. 
Qori'a, C. G. 2014. Statistika Inferensial. Jember: Fakultas Ekonomi Universitas Jember.

Rachman, A. N., S. M. Rahayu, dan Topowijono. 2015. Pengaruh Good Corporate Governance dan Financial Leverage Terhadap Kinerja Keuangan dan Nilai Perusahaan. Jurnal Administrasi Bisnis (JAB). 27(1): 1-10.

Repi, S., S. Murni dan D. Adare. 2016. Faktor-faktor yang Mempengaruhi Nilai Perusahaan Subsektor Perbankan pada BEI dalam Menghadapi MEA. Jurnal EMBA. 4(1): 181-191.

Rini, D. P. dan Winarno. 2014. Pengaruh Profitabilitas, Keputusan Pendanaan, Keputusan Investasi, dan Keputusan Dividen Terhadap Nilai Perusahaan Pada Perusahaan Yang Termasuk Dalam Indeks LQ45. Jurnal Universitas Negeri Yogyakarta: 73-81.

Rinnaya, I. Y., R. Andini dan A. Oemar. 2016. Pengaruh Profitabilitas, Keputusan Pendanaan, Keputusan Investasi Terhadap Nilai Perusahaan. Journal of Accounting. 2(2).

Riyanto, B. 1995. Dasar-dasar Pembelanjaan Perusahaan. Edisi Keempat. Yogyakarta: Yayasan Penerbit Gajah Mada.

Rochaety, E., R. Tresnati dan H. A. M. Latief. 2007. Metode Penelitian Bisnis dengan Aplikasi SPSS. Jakarta : Mitra Wacana Media.

Rohmah dan N. Aida. 2016. Pengaruh Kebijakan Hutang, Profitabilitas, dan Ukuran Perusahaan Terhadap Nilai Perusahaan Pada Perusahaan Manufaktur Sub Sektor Food and Beverage yang Terdaftar di BEI Tahun 2011-2015. Jurnal STIE Bisnis Indonesia: 33-44.
Rudangga, I. G. N. G. dan I. G. M. Sudiarta. 2016. Pengaruh Ukuran Perusahaan, Leverage, dan Profitabilitas Terhadap Nilai Perusahaan. E-Jurnal Manajemen Unud. 5(7): 4394-4422.

Santoso, S. 2013. Menguasai SPSS 21 di Era Informasi. Jakarta : PT Elex Media Komputindo.

Sartono, A. 2010. Manajemen Keuangan teori dan Aplikasi. Edisi Keempat. Yogyakarta : BPFE.

Sarwono, J. 2017. Mengenal ProsedurProsedur Populer dalam SPSS 23. Jakarta : PT Elex Media Komputindo.

Senata, M. 2016. Pengaruh Kebijakan Dividen Terhadap Nilai Perusahaan yang Tercatat pada Indeks LQ-45 Bursa Efek Indonesia. Jurnal Wira Ekonomi Mikroskil. 6(1): 73-84.

Singarimbun, M. dan S. Effendi. 2006. Metode Penelitian Survei. Jakarta : LP3ES.

Sjahrial, D. 2007. Manajemen Keuangan. Jakarta : Mitra Wacana Media

Suastini, N. M., I. B. A. Purbawangsa dan H. Rahyuda. 2016. Pengaruh Kepemilikan Manajerial dan Pertumbuhan Perusahaan Terhadap Nilai Perusahaan Pada Perusahaan Manufaktur di Bursa Efek Indonesia. E-Jurnal Ekonomi dan Bisnis Universitas Udayana. 5(1): 143-172.

Sudarmanto, R. G. 2013. Statistik Terapan Berbasis Komputer Dengan Program IBM SPSS Statistics 19. Jakarta : Penerbit Mitra Wacana Media.

Sudiyatno, B., E. Puspitasari dan A. Kartika. 2012. The Company's Policy, Firm Performance, and Firm Value: An Empirical Research on Indonesia 
Stock Exchange. American International Journal Of Contemporary Research. 2(12): 30-40.

Sugiyono. 2014. Metode Penelitian Kuantitatif Kualitatif Dan R\&D. Cetakan ke-21. Bandung : Alfabeta.

Sugiyono dan A. Susanto. 2015. Cara Mudah Belajar SPSS \& LISREL. Bandung : Alfabeta.

Sumarsono, H. 2012. Pengaruh Keputusan Pendanaan, Kebijakan Deviden dan Pertumbuhan Perusahaan Terhadap Nilai Perusahaan. Jurnal Ekulilibrium. 10(1): 36-46.

Supangat, Andi. 2010. Statistik Dalam Kajian Deskriptif, Inferensi, dan Nonparametrik. Jakarta : Kencana Prenada Media Group.

Suroto. 2015. Pengaruh Keputusan Investasi, Keputusan Pendanaan dan Kebijakan Dividen Terhadap Nilai Perusahaan (Studi Empiris Pada Perusahaan LQ-45 Yang Terdaftar Di Bursa Efek Indonesia Periode Februari 2010Januari 2015). Serat Acitya - Jurnal Ilmiah UNTAG Semarang. 4(3): 100-117.

Suryaningsih, I., R. Andini dan A. Oemar. 2018. Pengaruh Kepemilikan Manajemen, Ukuran Dewan Komisaris \& Kebijakan Dividen Terhadap Nilai Perusahaan Dengan Corporate Social Responsibility Sebagai Variabel Moderating. Journal of Accounting 2018.1-20.

Sutrisno. 2013. Manajemen Keuangan : Teori Konsep \& Aplikasi. Yogyakarta : Penerbit Ekonisia.

Suwardika I. N. A. dan I. K. Mustanda. 2017. Pengaruh Leverage, Ukuran Perusahaan, dan Profitabilitas
Terhadap Nilai Perusahaan Pada Perusahaan Properti. E-Jurnal Manajemen UNUD. 6(3): 1248-1277.

Syamsudin, L. 2011. Manajemen Keuangan Perusahaan. Jakarta : Rajawali Pers.

Tandelilin, E. 2010. Portofolio dan Investasi Teori dan Aplikasi. Edisi Pertama. Yogyakarta : Kanisius.

Toin, D. R. Y. dan Sutrisno. 2015. Pengaruh Faktor Internal dan Eksternal Terhadap Harga Saham Industri Perdagangan Eceran di Bursa Efek Indonesia. Among Makarti. 8 (16): 12-22.

Utomo, N. A. dan N. N. A. Christy. 2017. Pengaruh Struktur Modal, Profitabilitas, Ukuran Perusahaan Terhadap Nilai Perusahaan LQ45 Di Bursa Efek Indonesia. Bima Bangkai Manajemen Pascasarjana STIE Dharmaputra Semarang : 398-415.

Wayudi, U. dan H. P. Pawestri. 2006. Implikasi Struktur Kepemilikan Terhadap Nilai Perusahaan: Dengan Keputusan keuangan Sebagai Variabel Intervening. Simposium Nasional Akuntansi 9 Padang.

Wahyuni, T., E. Ernawati dan W. R. Murhadi. 2013. Faktor-faktor yang Mempengaruhi Nilai Perusahaan di Sektor Property, Real estate dan Building Construction yang Terdaftar di BEI Periode 2008-2012. Jurnal Ilmiah Mahasiswa Universitas Surabaya. 2(1): 1-18.

Wongso, A. 2012. Pengaruh Kebijakan Deviden, Struktur Kepemilikan dan Kebijakan Hutang Terhadap Nilai Perusahaan dalam Perspektif Teori Agensi dan Teori Signaling. Jurnal Akuntansi. 